\title{
Problematika Pengaturan Tindak Lanjut Putusan Mahkamah Konstitusi Dalam Perkara Pidana Oleh Mahkamah Agung
}

\author{
Ni'matul Huda \\ Fakultas Hukum Universitas Islam Indonesia Yogyakarta Indonesia \\ Jln. Taman Siswa 158, Yogyakarta Indonesia \\ 904100108@uii.ac.id
}

Received: 15 September 2020; Accepted: 20 Oktober 2020; Published: 15 Desember 2020

https://doi.org/10.20885/iustum.vol27.iss3.art1

\begin{abstract}
There are several decisions of the Constitutional Court (MK) regarding judicial review which are not only difficult to implement in practice but also followed-up in a variety of ways. Several norms in the Criminal Code (KUHP) and the Criminal Procedure Code (KUHAP), are some of those that are often petitioned for review at the Constitutional Court. There are two main problems in this paper, first, how is the implementation of the Constitutional Court decision in a criminal case followed-up by the Supreme Court (MA)? Second, how should the Supreme Court's decision follow-up in criminal cases? This study concludes, first, the follow-up after the Constitutional Court's decision (especially judicial review) in criminal cases by the Supreme Court in the form of Supreme Court Circular Letter (SEMA), Supreme Court Regulations (PERMA), and there are even those who ignore the Constitutional Court's decision because the Supreme Court's decision still rests on the provisions that have been canceled by the Court. Second, to follow-up on the Constitutional Court's decision by the Supreme Court in a criminal case, a legal product in the form of a Supreme Court Regulation must be issued. This is necessary for the smooth running of the judiciary or to fill legal gaps and loopholes resulting from the Constitutional Court's decision. For this reason, the People's Representative Council (DPR) and the Government should immediately revise the Criminal Code and Criminal Procedure Code so as not to create a legal vacuum, so as to provide justice and legal certainty for the community.
\end{abstract}

Key Words: Cases Constitutional Court's decision; criminal cases; follow-up

Abstrak

Ada beberapa Putusan Mahkamah Konstitusi (MK) tentang pengujian undang-undang dalam praktik tidak hanya sulit diimplementasikan tetapi juga ditindaklanjuti secara beragam. Beberapa norma di dalam Kitab Undang-Undang Hukum Pidana (KUHP) dan Kitab Undang-Undang Hukum Acara Pidana (KUHAP) termasuk yang sering dimohonkan pengujian ke MK. Permasalahan utama dalam tulisan ini ada dua, pertama, bagaimana implementasi putusan MK dalam perkara pidana ditindaklanjuti oleh Mahkamah Agung (MA)? Kedua, bagaimana seharusnya tindak lanjut putusan MK oleh MA dalam perkara pidana? Kajian ini menyimpulkan, pertama, tindak lanjut pasca putusan MK (terutama pengujian undang-undang) dalam perkara pidana oleh MA berupa Surat Edaran MA (SEMA), Peraturan MA (PERMA), bahkan ada pula yang tidak menghiraukan putusan MK karena dalam menjatuhkan putusan MA masih berpijak pada ketentuan yang telah dibatalkan oleh MK tersebut. Kedua, untuk menindaklanjuti putusan MK oleh MA dalam perkara pidana harus dikeluarkan produk hukum berbentuk Peraturan MA. Hal itu diperlukan untuk kelancaran penyelenggaraan peradilan atau untuk mengisi kekurangan dan kekosongan hukum akibat putusan MK. Untuk itu, seharusnya Dewan Perwakilan Rakyat (DPR) dan Pemerintah segera merevisi KUHP dan KUHAP agar tidak menimbulkan kekosongan hukum, sehingga dapat memberikan keadilan dan kepastian hukum bagi masyarakat.

Kata-kata Kunci: Tindak lanjut; putusan Mahkamah Konstitusi; perkara pidana 


\section{Pendahuluan}

Mahkamah Konstitusi (MK) sebagai lembaga negara (baru) produk reformasi, menjadi tumpuan ekspektasi masyarakat yang menginginkan terjadinya perbaikan dalam bidang penegakan hukum. MK sudah membuktikan sebagai institusi hukum yang dapat dipercaya dan terhormat (reliable and honoured court) di Indonesia. Hal ini dibuktikan dengan banyaknya putusan-putusan Mahkamah Konstitusi yang sangat progresif dan dapat menjadi acuan hukum bagi percepatan reformasi hukum di Indonesia. Sejak Agustus 2003 hingga 2019, MK telah melahirkan sebanyak 1.258 putusan pengujian undang-undang, 25 putusan Sengketa Kewenangan Lembaga Negara, 1.236 putusan perselisihan hasil pemilihan umum, dan 982 putusan perselisihan hasil pemilihan kepala daerah. Dari beberapa putusan MK tersebut terdapat putusan-putusan yang bersifat monumental dan fundamental dalam menegakkan Undang-Undang Dasar Negara Republik Indonesia Tahun 1945 (UUD NRI 1945) yang biasa disebut sebagai landmark decision. ${ }^{1}$

Data putusan dari website MK, sejak tahun 2003 hingga Desember 2017 terdapat 5 undang-undang terbanyak yang diujikan ke MK, yaitu Kitab UndangUndang Hukum Acara Pidana (KUHAP) 58 kali, Undang-Undang tentang Mahkamah Agung (UU MA) 35 kali, UU tentang MK 30 kali, UU tentang Komisi Pemberantasan Korupsi (KPK) 21 kali, UU tentang Majelis Permusyawaratan Rakyat, Dewan Perwakilan Rakyat, Dewan Perwakilan Rakyat Daerah, Dewan Perwakilan Daerah (UU MD3) sebanyak 20 kali dan UU tentang Ketenagakerjaan sebanyak 20 kali.

Meskipun telah banyak undang-undang yang diputuskan pengujiannya oleh MK, namun dalam pelaksanaan putusan MK tersebut, ada beberapa putusan yang tidak berjalan sebagaimana mestinya atau tidak ditaati oleh lembaga adressat-nya. ${ }^{2} \mathrm{Di}$ samping itu, ada persoalan lain yang menarik untuk dikaji, yakni terkait tindak lanjut pasca putusan MK (terutama pengujian UU) dalam perkara pidana oleh Mahkamah Agung (MA). Ada yang ditindaklanjuti oleh MA dengan mengeluarkan Surat Edaran (SEMA), ada yang diatur dalam Peraturan MA (PERMA), bahkan ada

${ }^{1}$ Lihat dalam Tim Penyusun Buku, Putusan Landmark Mabkamah Konstitusi 2014-2016, Kepaniteraan dan Sekretariat Jenderal Mahkamah Konstitusi, Jakarta, 2017, hlm. viii.

${ }^{2}$ Ni'matul Huda, Kekuatan Eksekutorial Putusan Mabkamah Konstitusi, FH UII Press, Yogyakarta, 2018, hlm. 219-220. 
pula yang tidak dihiraukan oleh MA karena dalam menjatuhkan putusan MA masih berpijak pada ketentuan yang telah dibatalkan oleh MK tersebut.

Dalam Pasal 24C ayat (1) UUD NRI Tahun 1945 telah ditegaskan bahwa "Mahkamah Konstitusi berwenang mengadili pada tingkat pertama dan terakhir yang putusannya bersifat final untuk menguji undang-undang terhadap UndangUndang Dasar...". Penegasan tersebut dinyatakan kembali dalam Pasal 10 ayat (1) UU MK yang berbunyi “Mahkamah Konstitusi berwenang mengadili pada tingkat pertama dan terakhir yang putusannya bersifat final untuk menguji undang-undang terhadap Undang-Undang Dasar...". Putusan MK yang bersifat final dan mengikat tersebut dapat dikatakan bahwa terhadap putusan tersebut tidak dapat dilakukan upaya hukum baik kasasi maupun peninjauan kembali. Putusan ini wajib dihormati dan dilaksanakan oleh pemerintah dan lembaga negara lainnya maupun masyarakat pada umumnya yang terkait dengan putusan tersebut. ${ }^{3}$

UU MK secara normatif, tidak menjelaskan lebih lanjut apa bentuk payung hukum sebuah norma yang sudah diputus oleh MK melalui pengujian undangundang. Di dalam Pasal 57 ayat (3) UU MK hanya ditegaskan bahwa "Putusan Mahkamah Konstitusi yang mengabulkan permohonan wajib dimuat dalam Berita Negara RI dalam jangka waktu paling lama 30 hari kerja sejak putusan ditetapkan".

Bagaimana tindak lanjut pengaturan pasca putusan MK terkait pengujian undang-undang? Di dalam Pasal 59 ayat (2) UU MK ditentukan, "Jika diperlukan perubahan terhadap undang-undang yang telah diuji, DPR atau Presiden segera menindaklanjuti putusan Mahkamah Konstitusi sebagaimana dimaksud pada ayat (1) sesuai dengan peraturan perundang-undangan". Akan tetapi, ketentuan dalam Pasal 59 ayat (2) tersebut sejak Selasa 18 Oktober 2011 telah diuji oleh MK dan dinyatakan tidak lagi mempunyai kekuatan hukum mengikat berdasarkan putusan MK No. 49/PUU-IX/2011. Dengan demikian, UU MK tidak lagi mengatur tindak lanjut pasca putusan MK.

Tindak lanjut pengaturan pasca putusan MK dapat diketemukan setidaknya di dalam UU No. 12 Tahun 2011 tentang Pembentukan Peraturan Perundang-

3 Tim Penyusun Buku Hakim Konstitusi Prof. H.A.S. Natabaya, SH, LLM, Menata Ulang Sistem Peraturan Perundang-Undangan Indonesia, Jejak Langkah dan Pemikiran Hukum Prof. H.A.S. Natabaya, SH, LLM, (Hakim Konstitusi Periode 2003-2008), Sekretariat Jenderal dan Kepaniteraan Mahkamah Konstitusi, Jakarta, 2008, hlm. 286-287. 
undangan, Pasal 10 ayat (1) huruf d, menentukan "materi muatan yang harus diatur dengan Undang-Undang berisi tindak lanjut atas putusan Mahkamah Konstitusi; dan/atau". Kemudian pada ayat (2) ditegaskan, "Tindak lanjut atas putusan Mahkamah Konstitusi sebagaimana dimaksud pada ayat (1) huruf d dilakukan oleh DPR atau Presiden." Penjelasan atas ketentuan Pasal 10 ayat (1) huruf $d$ menentukan, yang dimaksud dengan "tindak lanjut atas putusan Mahkamah Konstitusi" terkait dengan putusan MK mengenai pengujian UU terhadap UUD NRI Tahun 1945. Materi muatan yang dibuat, terkait dengan ayat, pasal, dan/atau bagian UU yang secara tegas dinyatakan dalam Putusan MK bertentangan dengan UUD NRI Tahun 1945. Kemudian dalam Penjelasan ayat (2) ditentukan, "tindak lanjut atas putusan MK dimaksudkan untuk mencegah terjadinya kekosongan hukum".

Setidaknya dijumpai 2 masalah pada tataran implementasi putusan, yaitu: pertama, delegitimasi putusan, hal ini dapat dilihat dari sejauh mana tingkat ketaatan para pihak, terutama pemerintah dan pihak-pihak yang terkait putusan lainnya untuk mematuhi dan melaksanakan putusan Mahkamah Konstitusi. Kedua, tidak ada sanksi yang tegas bagi siapa saja yang tidak mematuhi putusan Mahkamah Konstitusi tersebut. ${ }^{4}$ Beranjak dari berbagai permasalahan di atas, tentunya penelitian ini menjadi sangat urgen guna memberikan masukan atas riset ilmu hukum khususnya mengenai diskursus tindak lanjut putusan MK oleh MA dalam perkara pidana yang masih cukup terbatas.

\section{Rumusan Masalah}

Berdasarkan latar belakang permasalahan tersebut, maka diajukan permasalahan yang akan dikaji dalam penelitian ini, pertama, bagaimana implementasi putusan MK dalam perkara pidana ditindaklanjuti oleh MA? Kedua, bagaimana seharusnya tindak lanjut putusan MK oleh MA dalam perkara pidana?

\section{Tujuan Penelitian}

Berdasarkan rumusan masalah di atas, maka tujuan penelitian ini yaitu untuk mengetahui, pertama, implementasi putusan MK dalam perkara pidana ditindaklanjuti oleh MA. Kedua, tindak lanjut putusan MK oleh MA dalam perkara pidana yang ideal.

${ }^{4}$ Martitah, Mabkamah Konstitusi Dari Negative Legislature ke Positive Legislature, Konpress, Jakarta, 2013, hlm. 225. 


\section{Metode Penelitian}

Penelitian ini merupakan penelitian hukum normatif. Objek penelitiannya adalah tindak lanjut putusan Mahkamah Konstitusi dalam perkara pidana oleh Mahkamah Agung. Menggunakan pendekatan kasus, pendekatan perundangundangan, dan pendekatan konseptual. Pendekatan kasus digunakan untuk mengetahui dasar-dasar pertimbangan hakim konstitusi dalam membuat putusan pengujian undang-undang. Pendekatan perundang-undangan digunakan untuk menganalisis implementasi putusan Mahkamah Konstitusi oleh Mahkamah Agung dalam perkara pidana. Pendekatan konseptual digunakan untuk mengajukan gagasan pengaturan yang seharusnya dilakukan oleh Mahkamah Agung dalam meniundaklanjuti putusan Mahkamah Konstitusi dalam perkara pidana.

\section{Hasil Penelitian dan Pembahasan}

\section{Kekuatan Hukum Putusan}

Dalam UUD NRI Tahun 1945 Pasal 24C jo UU MK, telah ditegaskan bahwa putusan MK bersifat final, yaitu langsung mempunyai kekuatan hukum tetap dan tidak terdapat upaya hukum untuk mengubahnya. Muncul keresahan di masyarakat berkaitan dengan tindak lanjut putusan MK yang menggugurkan atau membatalkan suatu norma di dalam pengujian peraturan perundang-undangan. Diidentifikasi, ada beberapa putusan MK tentang pengujian undang-undang yang tidak ditindaklanjuti oleh Pemerintah atau pun DPR dalam pembentukan peraturan perundang-undangan, bahkan DPR dan/atau Pemerintah memunculkan kembali norma yang sudah dibatalkan oleh MK ke dalam RUU yang baru. Demikian pula yang terjadi di MA. Putusan-putusan MK yang menguji tentang perbuatan melawan hukum materiil dalam tindak pidana korupsi, ${ }^{5}$ atau penerapan Pasal $160 \mathrm{Kitab}$ Undang-Undang Hukum Pidana (KUHP) sebagai delik materiil, 6 misalnya, juga tidak ditindaklanjuti, dengan alasan MA tidak harus terikat dengan putusan MK, karena di MA mengikuti prinsip yurisprudensi.

\footnotetext{
${ }^{5}$ Lihat Putusan MK No. 003/PUU-IV/2006 bertanggal 25 Juli 2006 tentang Perbuatan Melawan Hukum Materiil dalam Tindak Pidana Korupsi.

${ }^{6}$ Lihat Putusan MK No. 7/PUU-VII/2009 bertanggal 22 Juli 2009 tentang Penerapan Pasal 160 KUHP sebagai delik materiil.
} 
Pertanyaan yang muncul, siapakah yang bisa memaksa supaya Putusan MK ditaati dan ditindaklanjuti oleh lembaga negara lainnya? Putusan MK sifatnya declaratoir, sehingga dilaksanakan atau tidak oleh Pemerintah atau DPR atau pun MA, sangat bergantung dari political will lembaga tersebut. Hal ini juga harus ada jalan keluarnya, agar putusan-putusan MK tidak sekedar 'macan ompong'. ${ }^{7}$

Putusan MK sebagaimana telah diuraikan di atas, kebanyakan jenisnya terutama dalam pengujian undang-undang adalah bersifat declaratoir constitutief. Artinya putusan MK tersebut menciptakan atau meniadakan satu keadaan hukum baru atau membentuk hukum baru sebagai negative legislator yang disebut Hans Kelsen adalah melalui satu pernyataan. Sifat yang declaratoir demikian tidak membutuhkan satu aparat yang melakukan pelaksanaan putusan hakim MK. Eksekusi demikian dibutuhkan dalam jenis-jenis putusan pengadilan biasa condemnatoir yang menghukum salah satu pihak untuk melakukan sesuatu, misalnya membayar sejumlah uang. ${ }^{8}$ Demikian juga putusan MK yang memuat amar yang menyatakan bagian UU atau pasal/ayat tertentu tidak mempunyai kekuatan mengikat sejak diumumkan dalam sidang terbuka untuk umum. Namun, sebagai syarat untuk diketahui secara umum, putusan demikian diumumkan dalam Berita Negara dalam jangka waktu paling lambat 30 hari sejak putusan diucapkan. Tidak dibutuhkan adanya satu aparat khusus untuk melaksanakan putusan tersebut, karena sifatnya hanya declaratoir. ${ }^{9}$

Kalau pemerintah atau lembaga negara lain tidak mematuhi putusan tersebut dan justru masih tetap memberlakukan UU yang telah dinyatakan MK tidak mempunyai kekuatan hukum mengikat, hal itu merupakan satu tindakan yang pengawasannya ada dalam mekanisme hukum dan tata negara itu sendiri. Perbuatan yang dilakukan atas dasar UU yang sudah dinyatakan batal dan tidak mempunyai kekuatan hukum mengikat adalah merupakan perbuatan melawan hukum. ${ }^{10}$ Dari sudut konstitusi, perbuatan melawan hukum demikian jika dilakukan pemerintah atau presiden, boleh jadi akan memicu proses politik yang

\footnotetext{
${ }^{7}$ Ni'matul Huda, Perkembangan Hukum Tata Negara Perdebatan \& Gagasan Penyempurnaan, FH UII Press, Yogyakarta, 2014, hlm. 62

${ }^{8}$ Maruarar Siahaan, Hukum Acara Mabkamah Konstitusi RI, Konpress, Jakarta, 2005, hlm. 206.

${ }^{9}$ Ibid., hlm. 207.

10 Ibid.
} 
ada di DPR yang dapat bermuara bahwa Presiden akan tidak memenuhi syarat lagi menjadi Presiden karena alasan yang disebut dalam UUD NRI 1945.

Putusan MK sejak diucapkan di hadapan sidang terbuka untuk umum, dapat mempunyai 3 kekuatan, yaitu (1) kekuatan mengikat, (2) kekuatan pembuktian, dan (3) kekuatan eksekutorial. ${ }^{11}$ (1) Kekuatan mengikat. Mahkamah Konstitusi berwenang mengadili perkara konstitusi dalam tingkat pertama dan terakhir yang putusannya bersifat final. Itu berarti bahwa putusan MK langsung memperoleh kekuatan hukum tetap sejak diucapkan dan tidak ada upaya hukum yang dapat ditempuh. Putusan sebagai perbuatan hukum pejabat negara menyebabkan pihak-pihak dalam perkara tersebut akan terikat pada putusan dimaksud yang telah menetapkan apa yang menjadi hukum, baik dengan mengubah keadaan hukum yang lama maupun yang sekaligus juga menciptakan keadaan hukum yang baru. Pihak-pihak terikat pada putusan tersebut juga dapat diartikan bahwa pihak-pihak akan mematuhi perubahan keadaan hukum yang diciptakan dengan putusan tersebut dan melaksanakannya. ${ }^{12}$ Kekuatan mengikat putusan MK, berbeda dengan putusan pengadilan biasa, tidak hanya meliputi pihak-pihak berperkara yaitu Pemohon, Pemerintah, DPR/DPD ataupun pihak terkait yang diizinkan memasuki proses perkara, tetapi juga putusan tersebut juga mengikat bagi semua orang, lembaga negara dan badan hukum dalam wilayah Republik Indonesia. Ia berlaku sebagai hukum sebagaimana hukum diciptakan pembuat UU. Hakim MK dikatakan sebagai negative legislator yang putusannya bersifat erga omnes, yang ditujukan pada semua orang. ${ }^{13}$

(2) Kekuatan Pembuktian. Pasal 60 UU MK menentukan bahwa materi muatan ayat, pasal dan/atau bagian dalam UU yang telah diuji, tidak dapat dimohonkan untuk diuji kembali. Dengan demikian, adanya putusan Mahkamah yang telah menguji satu undang-undang, merupakan alat bukti yang dapat digunakan bahwa telah diperoleh satu kekuatan pasti (gezag van gewijsde).14 Dikatakan kekuatan pasti atau gezag van gewijsde tersebut bisa bersifat negatif maupun positif. Kekuatan pasti satu putusan secara negatif diartikan bahwa

11 Ibid., hlm. 208.

12 Ibid.

${ }^{13}$ Ibid., hlm. 209.

${ }^{14}$ Ibid. 
hakim tidak boleh lagi memutus perkara permohonan yang sebelumnya pernah diputus, sebagaimana disebut dalam Pasal 60 UU MK. Dalam perkara konstitusi, yang putusannya bersifat erga omnes, maka permohonan pengujian yang menyangkut materi yang sama yang sudah pernah diputus tidak dapat lagi diajukan untuk diuji oleh siapapun. Putusan MK yang telah berkekuatan hukum tetap demikian dapat digunakan sebagai alat bukti dengan kekuatan pasti secara positif bahwa apa yang diputus oleh hakim itu dianggap telah benar. Pembuktian sebaliknya tidak diperkenankan. ${ }^{15}$

(3) Kekuatan Eksekutorial. Sebagai satu perbuatan hukum pejabat negara yang dimaksudkan untuk mengakhiri sengketa yang akan meniadakan atau menciptakan hukum yang baru, maka tentu saja diharapkan bahwa putusan tersebut tidak hanya merupakan kata-kata mati di atas kertas. Sebagai putusan hakim, setiap orang kemudian akan berbicara bagaimana pelaksanaannya dalam kenyataan. Dikatakan bahwa putusan yang telah berkekuatan hukum tetap itu mempunyai kekuatan eksekutorial yaitu agar apa yang diputuskan dilaksanakan dan jika perlu dengan kekuatan paksa (met sterke arm). ${ }^{16}$

Apakah putusan MK memiliki kekuatan eksekutorial? Satu undang-undang yang sebelum diuji telah diumumkan dalam Lembaran Negara dan diterbitkan dalam satu bentuk yang utuh tidak akan dapat diketahui dan dipahami oleh semua orang yang terikat oleh putusan MK tersebut tanpa perubahan yang dilakukan sesuai dengan putusan MK, setidak-tidaknya dengan integrasi putusan MK dalam UU yang diterbitkan Sekretariat Negara. Meskipun putusan tersebut tetap dianggap mempunyai kekuatan eksekutorial seperti halnya putusan dalam hukum acara peradilan biasa, namun hal itu tidak memberi hak pada pemohon untuk meminta dilaksanakannya putusan tersebut dalam bentuk perubahan undang-undang yang telah diuji MK tersebut. ${ }^{17}$

Putusan MK sebagaimana telah diuraikan di atas, kebanyakan jenisnya terutama dalam pengujian undang-undang adalah bersifat declaratoir constitutief. Artinya putusan MK tersebut menciptakan atau meniadakan satu keadaan hukum baru atau membentuk hukum baru sebagai negative legislator yang disebut Hans

\footnotetext{
15 Ibid.

16Ibid., hlm. 210.

${ }^{17}$ Ibid., hlm. 211.
} 
Kelsen adalah melalui satu pernyataan. Sifat yang declaratoir demikian tidak membutuhkan satu aparat yang melakukan pelaksanaan putusan hakim MK. Eksekusi demikian dibutuhkan dalam jenis-jenis putusan pengadilan biasa condemnatoir yang menghukum salah satu pihak untuk melakukan sesuatu, misalnya membayar sejumlah uang. ${ }^{18}$ Demikian juga putusan MK yang memuat amar yang menyatakan bagian UU atau pasal/ayat tertentu tidak mempunyai kekuatan mengikat sejak diumumkan dalam sidang terbuka untuk umum. Namun sebagai syarat untuk diketahui secara umum, putusan demikian diumumkan dalam Berita Negara dalam jangka waktu paling lambat 30 (tiga puluh hari) sejak putusan diucapkan. Tidak dibutuhkan adanya satu aparat khusus untuk melaksanakan putusan tersebut, karena sifatnya hanya declaratoir. ${ }^{19}$

Menurut Maruara Siahaan, ${ }^{20}$ terdapat putusan MK dalam perkara pengujian undang-undang yang bersifat self-implementing dan non-self implementing. ${ }^{21}$ Putusan yang bersifat self implementing, diartikan bahwa putusan akan langsung efektif berlaku tanpa memerlukan tindak lanjut lebih jauh dalam bentuk kebutuhan berupa langkah-langkah implementasi perubahan undang-undang yang diuji. Dalam hal ini, dengan diumumkannya putusan MK dalam sidang terbuka untuk umum dan diumumkan dalam Berita Negara sebagai norma hukum baru, dapat segera dilaksanakan.

Adapun putusan MK yang bersifat non-self implementing, karena implementasi kebijakan publik yang baru tersebut membutuhkan dasar hukum yang baru sebagai dasar pelaksanaan kebijakan publik yang ditetapkan dalam putusan MK. Perubahan hukum yang terjadi dengan putusan atas undangundang yang diuji MK yang mengharuskan proses pembentukan undang-undang yang baru sesuai dengan politik hukum yang digariskan dalam Putusan MK,

\footnotetext{
${ }^{18}$ Ibid., hlm. 206.

${ }^{19}$ Ibid., hlm. 207.

${ }^{20}$ Lihat dalam Fajar Laksana dkk., "Implikasi dan Implementasi Putusan Mahkamah Konstitusi No. 5/PUU-X/2012 tentang SBI atau RSBI”, Jurnal Konstitusi, Vol. 10, No. 4, Desember 2013, Hlm. 743.

21 Martitah menggunakan istilah non self executing dan self executing. Jika putusan Mahkamah Konstitusi bersifat non self executing, maka pelaksanaannya harus menunggu perubahan UU. Untuk putusan Mahkamah Konstitusi yang bersifat self executing, putusannya langsung dilaksanakan. Martitah, Mabkamah Konstitusi..., Op.Cit., hlm. 212.
} 
dalam putusan yang bersifat non-self implementing, akan mengambil langkahlangkah hukum untuk menindaklanjuti putusan Mahkamah Konstitusi. ${ }^{22}$

Putusan yang bersifat non-self implementing tidak selalu mudah untuk diimplementasikan. Putusan MK yang telah membentuk hukum atau instrumen hukum baru dengan menyatakan satu undang-undang, pasal, ayat, dan/atau bagian dari undang-undang tidak lagi mempunyai kekuatan hukum mengikat, tidak didukung dengan suatu instrumen yang dapat memaksakan bahwa putusan tersebut harus dilaksanakan, baik melalui kekuatannya sendiri maupun dengan cara-cara lain yang berada di bawah kendali MK. ${ }^{23}$

Menurut ketentuan Pasal 60 ayat (1) UU MK menegaskan, "Terhadap materi muatan ayat, pasal, dan/atau bagian dalam undang-undang yang telah diuji, tidak dapat dimohonkan pengujian kembali." Ayat (2) menegaskan, "Ketentuan sebagaimana dimaksud pada ayat (1) dapat dikecualikan jika materi muatan dalam Undang-Undang Dasar Negara RI Tahun 1945 yang dijadikan dasar pengujian berbeda." Permasalahan yang berpotensi muncul, pertama, jika peraturan yang menindaklanjuti putusan MK tersebut meskipun berupa undang-undang tetapi memuat kembali norma yang telah dibatalkan oleh MK. Hal ini dapat dilihat pada tindak lanjut Putusan MK No. 92/PUU-X/2012 tentang pengujian UU No. 27 Tahun 2009 tentang MPR, DPR, DPD dan DPRD dan UU No. 12 Tahun 2011 tentang Pembentukan Peraturan Perundang-undangan. Kedua, jika tindak lanjut putusan MK diatur dalam peraturan yang tingkatannya berada di bawah undang-undang misalnya Peraturan KPU atau Peraturan Pemerintah, Peraturan MA (PERMA), Peraturan Menteri, bahkan Perdasus, dan peraturan tersebut ternyata mengandung cacat yuridis atau tidak sesuai dengan putusan MK, maka peraturan tersebut tidak dapat diajukan permohonan pengujian ke MK, tetapi harus ke Mahkamah Agung

22 Sebagaimana yang ditentukan dalam Pasal 10 ayat (1) huruf d UU No. 12 Tahun 2011 tentang Pembentukan Peraturan Perundang-undangan bahwa: "materi muatan yang harus diatur dengan Undang-undang berisi: tindak lanjut atas putusan Mahkamah Konstitusi." Penjelasan Pasal 10 ayat (1) huruf d menyatakan: "Yang dimaksud dengan "tindak lanjut atas Putusan Mahkamah Konstitusi" terkait dengan putusan Mahkamah Konstitusi mengenai pengujian Undang-Undang terhadap UUD NRI Tahun 1945. Materi muatan yang dibuat, terkait dengan ayat, pasal, dan/atau bagian Undang-Undang yang secara tegas dinyatakan dalam putusan Mahkamah Konstitusi bertentangan dengan UUD NRI Tahun 1945.” Kemudian di ayat (2) ditegaskan: “Tindak lanjut atas putusan Mahkamah Konstitusi sebagaimana dimaksud pada ayat (1) huruf d dilakukan oleh DPR atau Presiden." Penjelasan ayat (2) menyatakan bahwa: "Tindak lanjut atas Putusan Mahkamah Konstitusi dimaksudkan untuk mencegah terjadinya kekosongan hukum.”

${ }^{23}$ Fajar Laksana dkk., "Implikasi dan..., Loc. Cit. 
(MA). Bagaimana kalau argumentasi dan pandangan hukum hakim di MA berbeda dengan hakim MK? Tidak mustahil hal itu pun bisa saja terjadi.

\section{Praktik Tindak Lanjut Putusan MK oleh MA}

Terkait dengan perkara pidana, ada beberapa norma dalam undang-undang yang telah diuji ke $\mathrm{MK}$, antara lain:

1. Putusan MK No. 013/PUU-I/2003 tentang Pemberlakuan Asas Retroaktif Bagi Tindak Pidana Terorisme.

2. Putusan MK No. 003/PUU-IV/2006 bertanggal 25 Juli 2006 tentang Perbuatan Melawan Hukum Materiil dalam Tindak Pidana Korupsi.

3. Putusan MK No. 003-022/PUU-IV/2006 tentang Pengujian Pasal 134, Pasal 136bis, dan Pasal 137 KUHP tentang Penghinaan terhadap Presiden dan/atau Wakil Presiden RI.

4. Putusan MK No. 2-3/PUU-V/2007 tentang Pengujian UU No. 22 Tahun 1997 tentang Narkotika (Konstitusionalitas Hukuman Mati).

5. Putusan MK No. 06/PUU-V/2007 tentang Delik Pidana Penyebaran Rasa Permusuhan, Kebencian atau Penghinaan terhadap Penguasa (haatzai artikelen).

6. Putusan MK No. 7/PUU-VII/2009 bertanggal 22 Juli 2009 tentang Penerapan Pasal 160 KUHP Sebagai Delik Materiil.

7. Putusan MK No. 34/PUU-XI/2013 tentang Peninjauan Kembali Tidak Dibatasi Hanya Satu Kali.

8. Putusan MK No. 21/PUU-XII/2014 bertanggal 28 April 2015 tentang Penetapan Tersangka Masuk Lingkup Praperadilan.

9. Putusan MK No. 107/PUU-XIII/2015 tentang Inkonstitusionalitas Pembatasan Jangka Waktu Pengajuan Permohonan Grasi.

10. Putusan MK No. 21/PUU-XIV/2016 tentang Permufakatan Jahat dalam Tindak Pidana Korupsi.

11. Putusan MK No. 33/PUU-XIV/2016 bertanggal 12 Mei 2016 tentang Peninjauan Kembali.

Ditengarai, beberapa Putusan MK tentang pengujian undang-undang tidak hanya tidak ditindaklanjuti oleh Pemerintah atau pun DPR dengan merevisi atau membentuk undang-undang baru, tetapi juga tidak diikuti oleh MA. Putusanputusan MK yang menguji tentang perbuatan melawan hukum materiil dalam tindak pidana korupsi, ${ }^{24}$ atau penerapan Pasal 160 KUHP sebagai delik materiil,25 misalnya, juga tidak ditindaklanjuti oleh MA, dengan alasan MA tidak harus

${ }^{24}$ Lihat Putusan MK No. 003/PUU-IV/2006 bertanggal 25 Juli 2006 tentang Perbuatan Melawan Hukum Materiil dalam Tindak Pidana Korupsi.

${ }^{25}$ Lihat Putusan MK No. 7/PUU-VII/2009 bertanggal 22 Juli 2009 tentang Penerapan Pasal 160 KUHP sebagai delik materiil. 
terikat dengan putusan Mahkamah Konstitusi, karena di MA mengikuti prinsip yurisprudensi. 26

Dari beberapa putusan MK tersebut dalam perkara pidana di dalam praktiknya ditindaklanjuti secara beragam oleh MA. Misalnya: pertama, Putusan MK No. 4/PUU-V/2007 tentang Pengujian secara materiil terhadap Pasal 75 ayat (1), Pasal 76, dan Pasal 79 UU No. 29 Tahun 2007 tentang Praktek Kedokteran. Melalui putusan tersebut MK telah menghapus pidana penjara dalam pasal tersebut. Menurut Mahkamah, ancaman pidana penjara paling lama tiga tahun, yang ditentukan dalam Pasal 75 ayat (1) dan Pasal 76 UU Praktik Kedokteran, serta pidana kurungan paling lama satu tahun sebagaimana diatur dalam Pasal 79 tidak proporsional. Sehingga menimbulkan ancaman dan rasa takut terhadap dokter atau dokter gigi dalam melakukan praktik kedokteran dalam memberikan pelayanan kesehatan kepada masyarakat. Namun, dalam Putusan MA No. 1110K/Pid.Sus/2012 tanggal 30 Oktober 2013 Hakim Agung masih menjatuhkan putusan yang berpijak pada pasal tersebut.

Kedua, Putusan MK No. 003/PUU-IV/2006 pengujian terhadap Pasal 2 ayat (1) dan Pasal 3 UU No. 31 Tahun 1999 jo UU No. 20 Tahun 2001 tentang Pemberantasan Tindak Pidana Korupsi, dimana dalam putusan tersebut MK telah menghapuskan sifat melawan hukum materiil dari UU Tipikor. Namun MA masih menggunakan penafsiran dan ajaran sifat melawan hukum materiil berdasarkan yurisprudensi. Contohnya Putusan MA No. 103K/Pid/2007. Menurut Hakim Agung Putusan MK tersebut membuat makna melawan hukum dalam Pasal 2 ayat (1) UU Tipikor menjadi tidak jelas, sehingga hakim harus menggali arti "melawan hukum" tersebut kepada nilai-nilai hukum yang berkembang dalam masyarakat pada saat ketentuan itu diterapkan dalam kasus konkrit. Hal ini berarti sifat melawan hukum dalam Pasal 2 ayat (1) masih dimaknai sebagai melawan hukum dalam arti luas. ${ }^{27}$

Ketiga, Putusan MK No. 34/PUU-IX/2013 tentang pengujian Pasal 268 ayat (3) UU No. 8 Tahun 1981 tentang Hukum Acara Pidana, dengan menyatakan bahwa ketentuan Pasal 268 ayat (3) bertentangan dengan UUD 1945 dan tidak mempunyai

${ }^{26}$ Ni'matul Huda, Kekuatan Eksekutorial..., Op.Cit, hlm. 209.

27 Lihat juga Putusan MA No. 996K/Pid/2006 dan Putusan MA No. 1974K/Pid/2006, yang tetap mempertahankan dan menerapkan perbuatan melawan hokum materiil pasca putusan MK. 
kekuatan hukum mengikat. Hal itu berarti upaya hukum luar biasa peninjauan kembali (PK) dapat diajukan lebih dari satu kali jika ditemukan novum. Akan tetapi, MA justru mengeluarkan SEMA No. 7 Tahun 2014 tentang Pengajuan Permohonan Peninjauan Kembali dalam Perkara Pidana, yang tetap membatasi PK hanya satu kali. ${ }^{28}$ Pasca putusan MK No. 34/PUU-IX/2013, MK juga mengeluarkan Putusan No. 45/PUU-XIII/2015, Putusan No. 66/PUU-XIII/2015 dan Putusan No. 108/PUUXIV/2016, yang menyatakan bahwa pokok permohonan menyangkut ketentuan Pasal 66 ayat (1) UU No. 14 Tahun 1985 jo UU No. 5 Tahun 2004, UU No. 3 Tahun 2009 dan ketentuan Psal 24 ayat (2) UU No. 48 Tahun 2009 secara mutatis mutandis berlaku pula Putusan MK No. 34/PUU-IX/2013.

Keempat, Putusan MK No. 013-022/PUU-IV/2006 tentang Pengujian Pasal 134, Pasal 136bis, dan Pasal 137 KUHP tentang Penghinaan terhadap Presiden dan/atau Wakil Presiden RI dinyatakan inkonstitusional dan tidak mempunyai kekuatan hukum mengikat. Dalam pertimbangan hukumnya Mahkamah Konstitusi mengemukakan bahwa Pasal 134, Pasal 136bis, dan Pasal 137 KUHP bisa menimbulkan ketidakpastian hukum (rechtsonzekerheid) karena amat rentan pada tafsir apakah suatu protes, pernyataan pendapat atau pikiran merupakan kritik atau penghinaan terhadap Presiden dan atau Wakil Presiden. Pasal 134, Pasal 136bis, dan Pasal 137 KUHP berpeluang pula menghambat hak atas kebebasan menyatakan pikiran dengan lisan, tertulis dan ekspresi sikap tatkala ketiga pasal pidana dimaksud selalu digunakan aparat hukum terhadap momentum-momentum unjuk rasa di lapangan. Namun, dalam Putusan MA No. 153PK/Pid/2010 tanggal 3 Agustus 2011 tetap mendasarkan putusannya pada Pasal-pasal 134, dan Pasal 136 KUHP yang telah dibatalkan oleh MK.

Kelima, Putusan MK No. 21/PUU-XII/2014 bertanggal 28 April 2015 tentang Penetapan Tersangka Masuk Lingkup Praperadilan. Putusan ini oleh MA dipandang memperluas kewenangan praperadilan sebagaimana dimaksud dalam ketentuan Pasal 77 huruf a KUHAP yang tidak hanya sebatas pada sah atau

${ }^{28}$ Dalil yang disampaikan oleh MA terkait SEMA tersebut, bahwa permintaan peninjauan kembali juga diatur dalam ketentun Pasal 24 ayat (2) UU No. 48 Tahun 2009 yang menyatakan, bahwa terhadap putusan peninjauan kembali tidak dapat dilakukan peninjauan kembali. Kemudian dalam Pasal 66 ayat (1) UU No. 14 Tahun 1985 jo UU No. 5 Tahun 2004, UU No. 3 Tahun 2009, menyebutkan bahwa permohonan peninjauan kembali hanya dapat diajukan satu kali. 
tidaknya penangkapan, penahanan, penghentian penyidikan atau penuntutan, tetapi termasuk juga penetapan tersangka, penyitaan dan penggeledahan. Di samping itu, Putusan MK No. 65/PUU-IX/2011 menghapus pemberian hak banding kepada penyidik dan penuntut umum sebagaimana dimaksud dalam Pasal 83 ayat (2) KUHAP sehingga terhadap putusan praperadilan tidak dapat lagi diajukan upaya hukum banding. Atas dasar dua Putusan MK tersebut MA mengeluarkan Peraturan MA (PERMA) No 4 Tahun 2016 tentang Larangan Peninjauan Kembali Putusan Praperadilan. PERMA ini antara lain didasarkan pada ketentuan Pasal 45A UU No. 5 Tahun 2004 tentang Perubahan atas UU No. 14 Tahun 1985 tentang Perubahan Kedua atas UU No. 3 Tahun 2009 tentang Mahkamah Agung yang menentukan larangan diajukan kasasi terhadap putusan Praperadilan. Di samping itu, menurut ketentuan Pasal 32 ayat (1) UU No. 14 Tahun 1985 yang telah diubah dengan UU No. 5 Tahun 2004 tentang Perubahan Kedua atas UU No. 3 Tahun 2009 tentang Mahkamah Agung memberikan kewenangan MA melakukan pengawasan tertinggi terhadap penyelenggaraan peradilan pada semua badan peradilan yang berada di bawahnya dalam menyelenggarakan kekuasaan kehakiman, termasuk Praperadilan.

Ketua MA Hatta Ali ketika menyampaikan sambutan dalam seminar tentang "Titik Singgung Wewenang antara MA dan MK" menyatakan:

"MA serta badan peradilan di bawahnya memiliki kewenangan untuk melakukan interpretasi terhadap ketentuan undang-undang dalam rangka menemukan kaidah hukum yang terkandung di dalamnya, terkait dengan perkara yang menjadi kewenangannya. Interpretasi yang dilakukan oleh hakim bertujuan untukmemberikan makna dan jiwa terhadap rumusan tekstual dalam undang-undang untuk disesuaikan dengan perkara yang diajukan kepadanya, tidak dalam posisi untuk menyatakan bahwa undangundang memiliki kekuatan mengikat atau tidak memiliki kekuatan mengikat. Namun demikian, penemuan hukum oleh hakim melalui metode interpretasi, terutama interpretasi ekstensif dan interpretasi antisipatif/futuristik telah menimbulkan berbagai perubahan besar dalam praktik penegakan dan pengembangan hukum."29

${ }^{29}$ Hatta Ali, Sambutan Ketua MA yang disampaikan dalam Seminar dengan tema "Titik Singgung Wewenang antara $M A$ dan $M K$ ”, yang diselenggarakan oleh Badan Litbang Diklat Kumdil MA RI, Jakarta, 13 November 2014. 
Sehubungan dengan deligitimasi putusan, menurut Maruarar Siahaan, kendala atau kesulitan dalam implementasi putusan MK lebih dikarenakan adanya pemahaman:

"Penyelenggara kekuasaan eksekutif dan legislatif yang diawasi dan dikontrol oleh hakim MK bertentangan dengan demokrasi. Dalam hal ini, produk penyelenggara kekuasaan eksekutif dan legislatif berupa undangundang dapat dibatalkan oleh sembilan orang hakim yang tidak dipilih oleh rakyat. Mengapa penyelenggara kekuasaan eksekutif dan legislatif yang dipilih langsung oleh rakyat justru diawasi dan dikontrol oleh hakim MK yang tidak dipilih secara langsung oleh rakyat. Karena pemikiran yang seperti itu, tidak jarang putusan MK diabaikan, terlebih lagi untuk putusan yang dipandang merugikan kepentingan politik mereka. Lembaga legislatif maupun eksekutif selaku pembentuk UU justru mewacanakan atau menunjukkan serangan balik untuk mengurangi kewenangan MK." 30

Dalam perkara pengujian UU, putusannya bersifat declaratoir constitutif, karena menyatakan apa yang menjadi hukum dari suatu norma undang-undang, yaitu bertentangan dengan UUD 1945. Pada saat yang bersamaan, putusan tersebut meniadakan keadaan hukum berdasarkan norma yang dibatalkan dan menciptakan keadaan hukum baru. Oleh karena putusan pengujian undangundang bersifat erga omnes, maka permohonan pengujian yang menyangkut materi yang sama yang sudah pernah diputus tidak dapat lagi diajukan untuk diuji oleh siapapun. Dengan demikian, putusan MK tersebut harus dijadikan acuan atau rujukan dalam memberlakukan hak dan kewenangannya.

\section{Idealita Pengaturan Tindak Lanjut oleh MA}

Terkait tindak lanjut putusan MK tentang pengujian undang-undang yang berkaitan dengan kewenangan Mahkamah Agung (MA) dalam perkara pidana, apakah harus dengan cara merevisi undang-undang yang bersangkutan atau membentuk undang-undang baru ataukah boleh dengan bentuk yang lain, misalnya diatur lebih lanjut dengan PERMA, SEMA, dan lain-lain. Keragaman peraturan yang menindaklanjuti putusan MK tersebut apa dasarnya? Apakah hal demikian memang dapat dibenarkan? Ataukah sudah seharusnya mengacu kepada

30 Maruarar Siahaan, UUD 1945 sebagai Konstitusi yang Hidup, Sekretariat Jenderal dan Kepaniteraan Mahkamah Konstitusi, Jakarta, 2008, hlm. 54. 
Pasal 10 ayat (1) dan (2) UU No. 12 Tahun 2011 tentang Pembentukan Peraturan Perundang-undangan, yaitu dengan merevisi UU atau membentuk UU baru.

Bagaimana dengan lembaga peradilan atau semacam Mahkamah Agung, dapatkah MA membentuk peraturan (perundang-undangan)? Menurut Jimly Asshiddiqie, produk hukum pengaturan yang ditetapkan oleh pejabat tertentu yang secara protokoler sederajat tidak dapat dikatakan selalu mengikuti tingkatan pejabat yang menetapkan. Kedudukan peraturan-peraturan yang ditetapkan oleh lembaga-lembaga khusus itu lebih tepat disebut juga sebagai peraturan yang bersifat khusus (lex specialis). Semua peraturan yang ditetapkan oleh lembaga khusus dan independen itu dapat diperlakukan sebagai bentuk peraturan khusus yang tunduk pada prinsip lex specialis derogat lex generalis. Termasuk dalam kategori ini, misalnya, adalah Peraturan Mahkamah Agung, Peraturan Mahkamah Konstitusi, Peraturan Bank Indonesia, Peraturan Komisi Pemilihan Umum, Peraturan Komisi Hak Asasi Manusia, Peraturan komisi Penyiaran Indonesia, Peraturan Pusat Pelaporan dan Analisa Transaksi Keuangan, dan sebagainya. 31 Badan atau lembaga-lembaga seperti ini dapat mengeluarkan peraturan tersendiri, asalkan kewenangan regulatif itu diberikan oleh Undang-Undang. Jika Lembaga-lembaga itu diberi kewenangan regulatif, maka nama produk regulatif yang dihasilkan sebaiknya disebut peraturan. ${ }^{32}$

MA di dalam menjalankan tugas dan wewenangnya di bidang peradilan dapat membentuk dan menetapkan peraturan untuk kepentingan pelaksanaan peradilan. Fungsi pengaturan yang merupakan kewenangan MA didasarkan pada Pasal 79 UU No. 14 Tahun 1985 sebagaimana telah diubah dan ditambah oleh UU No. 5 Tahun 2004 dan UU No. 3 Tahun 2009 yang menentukan: “MA dapat mengatur lebih lanjut hal-hal yang diperlukan bagi kelancaran penyelenggaraan peradilan, apabila terdapat hal-hal yang belum cukup diatur dalam UU ini". Kemudian dalam Penjelasan Pasal 79 ditentukan "Apabila dalam jalannya peradilan terdapat kekurangan atau kekosongan hukum dalam satu hal, MA berwenang membuat peraturan sebagai pelengkap untuk mengisi kekurangan dan kekosongan tersebut".

31 Jimly Asshiddiqie, Konstitusi \& Konstitusionalisme Indonesia, Diterbitkan atas kerjasama Mahkamah Konstitusi dengan Pusat Studi HTN FH Universitas Indonesia, Jakarta, 2004, hlm. 278-279.

${ }^{32}$ Ibid. 
Pendelegasian kewenangan pengaturan dapat dilakukan dengan tiga alternatif syarat, yaitu: 33

1. Adanya perintah yang tegas mengenai subjek lembaga pelaksana yang diberi delegasi kewenangan, dan bentuk peraturan pelaksana untuk menuangkan materi pengaturan yang didelegasikan;

2. Adanya perintah yang tegas mengenai bentuk peraturan pelaksana untuk menuangkan materi pengaturan yang didelegasikan; atau

3. Adanya perintah yang tegas mengenai pendelegasian kewenangan dari undang-undang atau lembaga pembentuk undang-undng kepada lembaga penerima delegasi kewenangan, tanpa penyebutan bentuk peraturan yang mendapat delegasi.

Jika mengacu kepada tiga alternatif syarat pendelegasian kewenangan pengaturan oleh MA sebagaimana disebutkan dalam Pasal 79 UU No. 14 Tahun 1985 di atas, maka perintah pendelegasiannya sudah tegas tetapi bentuk hukumnya tidak disebutkan secara tegas. Untuk membahas permasalahan tersebut ada tiga kemungkinan yang dapat dikembangkan, yaitu: ${ }^{34}$

1. Perintah pengaturan itu memang ada, tetapi tidak tegas menentukan bentuk peraturan apa yang dipilih sebagai tempat penuangan materi ketentuan yang didelegasikan pengaturannya;

2. Perintah pengaturan itu memang ada, tetapi tidak ditentukan dengan jelas lembaga yang diberi delegasi kewenangan ataupun bentuk peraturan yang harus ditetapkan untuk penuangan materi ketentuan yang didelegasikan;

3. Perintah pengaturan semacam itu sama sekali tidak disebut atau ditentukan dalam undang-undang yang bersangkutan, tetapi kebutuhan akan pengaturan semacamitu bersifat nyata dan tidak terelakkan dalam rangka pelaksanaan ketentuan undang-undang itu sendiri.

Apabila mengacu pada penegasan uraian tersebut di atas, perintah pengaturan itu memang ada, tetapi tidak tegas menentukan bentuk peraturan apa yang dipilih sebagai tempat penuangan materi ketentuan yang didelegasikan pengaturannya, maka MA dapat menentukan sendiri bentuk produk hukumnya, dalam hal ini dikeluarkanlah Peraturan MA (PERMA), yang telah sah menjadi sumber hukum formil karena ditentukan bentuknya sebagai peraturan dan berlaku umum, mengikat dan ditaati. Apalagi kehadiran PERMA sudah ada sejak

\footnotetext{
${ }^{33}$ Ibid., hlm.381-393.

${ }^{34}$ Ibid., hlm. 384-385
} 
tahun 1945 untuk mengisi kekosongan hukum, misalnya PERMA No. 1 Tahun 1945.35

Produk hukum PERMA tentu berbeda sifatnya dengan peraturan yang dibentuk oleh lembaga legislatif sebagai pembentuk Undang-Undang. Wewenang MA untuk membentuk peraturan hanya dibatasi dalam lingkup hukum acara. ${ }^{36}$ PERMA merupakan salah satu bentuk peraturan yang dikeluarkan oleh MA sebagai bagian dari kekuasaan administrasi negara, untuk mengatur dan menjalankan tugas pemerintahan di bidang peradilan. Oleh karena itu, PERMA sebagai fungsi pengaturan dapat dipahami sebagai pengisi kekosongan hukum dan sebagai pelengkap kekurangan hukum. ${ }^{37}$

PERMA dalam konteks memenuhi kebutuhan penyelenggaraan praktik peradilan dapat dipahami memiliki relevansi dengan situasi serta kondisi hukum yang berkembang. Oleh karena itu, peranan PERMA terkadang menjelma sebagai pengisi kekosongan hukum, pelengkap berlakunya ketentuan undang-undang yang belum ada peraturan organiknya, sebagai sarana penemuan hukum, sebagai sarana penegakan hukum, dan sebagai sumber hukum bagi hakim, dalam praktik penegakan hukum. ${ }^{38}$

Senada dengan pendapat Fauzan di atas, menurut Ronald, setidaknya ada 5 peran PERMA dalam memenuhi kebutuhan penyelenggaraan negara di bidang peradilan: 39

1. PERMA sebagai pengisi kekosongan hukum;

2. PERMA sebagai pelengkap ketentuan undang-undang yang kurang jelas mengatur tentang sesuatu hal berkaitan dengan hukum acara;

3. PERMA sebagai sarana penemuan hukum;

4. PERMA sebagai sarana penegakan hukum;

5. PERMA sebagai sumber hukum bagi masyarakat hukum (khususnya para hakim di dalam menyelesaikan kesulitan-kesulitan teknis penerapan hukum acara yang ternyata sudah tidak sesuai lagi dengan keadaan saat ini).

35 PERMA No. 1 Tahun 1945 diterbitkan untuk mengatur pelaksanaan keputusan pengadilan yang ternyata masih belum dapat dilaksanakan, walaupun terhadapnya tidak lagi dilakukan upaya hukum kasasi menurut Pasal 122 UU No. 1 Tahun 1950 tentang Mahkamah Agung Indonesia, sementara ketika itu ketentuan hukum acara belum mengatur tentang hal tersebut. Lihat dalam M. Fauzan, Peranan PERMA \& SEMA Sebagai Pengisi Kekosongan Hukum Indonesia Menuju Terwujudnya Peradilan yang Agung, Kencana Prenadamedia Group, Jakarta, 2013, hlm. ix.

${ }^{36}$ Ronald S. Lumbuun, PERMA RI Wujud Kerancuan Antara Praktik Pembagian dan Pemisaban Kekuasaan, Rajawali Pers, Jakarta, 2011, Hlm. 147.

${ }^{37}$ M. Fauzan, Peranan PERMA \&..., Op. Cit., Hlm. viii.

38 Ibid..

${ }^{39}$ Ronald S. Lumbuun, PERMA RI..., Op. Cit., Hlm. 14. 
Pertanyaan yang muncul, apakah tepat jikalau MA mengatur lebih lanjut putusan MK dengan mengeluarkan PERMA? Kehadiran PERMA setidaknya akan dapat menjadi alternatif pengisi kekosongan hukum. MA sebagai penyelenggara kekuasaan kehakiman tertinggi memiliki beberapa fungsi, antara lain fungsi pengaturan dalam rangka mengisi kekosongan hukum pasca putusan MK. Fungsi pengaturan diperlukan bagi kelancaran penyelenggaraan peradilan apabila terdapat hal-hal yang belum diatur dalam undang-undang atau terdapat kekurangan atau dalam hal ini kekosongan hukum pasca putusan MK.

Kewenangan MA membuat PERMA semata-mata bersifat pelengkap atau penyempurna terhadap peraturan perundang-undangan yang sudah ada, atau untuk mengisi kekosongan hukum, misalnya karena adanya putusan MK. Dengan pertimbangan apabila harus dibentuk atau merevisi undang-undang waktunya cukup panjang dan mungkin juga butuh biaya yang besar sehingga dipandang cukup diatur di luar undang-undang, maka ke depan harus dirumuskan konsep yang jelas dan tegas pengaturan sebagai tindak lanjut pasca putusan MK agar memberikan kepastian hukum dan keadilan. Di samping itu, juga dimaksudkan agar tercapai harmonisasi dan sinkronisasi pengaturan antar peraturan perundangundangan terkait. Ke depan, PERMA tidak boleh merupakan suatu peraturan yang berdiri sendiri tanpa ada sandaran atau dasar hukum yang jelas.

Bagaimana kalau pengaturan dalam PERMA sebagai tindak lanjut putusan MK bertentangan dengan Putusan MK atau bertentangan dengan UU? Siapakah yang berwenang melakukan pengujian? Mungkinkah MA akan menguji produk hukumnya sendiri (PERMA)? Bagaimana kalau argumentasi dan pandangan hukum hakim di MA berbeda dengan hakim MK? Hal itupun tidak mustahil bisa terjadi di belakang hari. Untuk itu, perlu diatur lebih lanjut persoalan apa saja dari norma undang-undang yang harus ditindaklanjuti dengan undang-undang dan apa saja yang dapat diatur dengan peraturan di bawah undang-undang, dalam konteks kewenangan MA, materi apa yang boleh diatur dengan PERMA.

\section{Penutup}

Setelah melakukan kajian terhadap dua permasalahan di atas, disimpulkan sebagai berikut. Pertama, implementasi putusan MK dalam perkara pidana yang 
ditindaklanjuti oleh MA secara beragam: (i) tetap memberlakukan pasal-pasal yang sudah dinyatakan bertentangan dengan UUD dan tidak mempunyai kekuatan hukum mengikat oleh MK. (ii) mengeluarkan Surat Edaran MA No. 7 Tahun 2014 tentang Pengajuan Permohonan Peninjauan Kembali dalam Perkara Pidana. (iii) mengeluarkan Peraturan MA (PERMA) No. 4 Tahun 2016 tentang Larangan Peninjauan Kembali Putusan Praperadilan.

Kedua, untuk menindaklanjuti putusan MK oleh MA dalam perkara pidana harus dikeluarkan produk hukum berbentuk Peraturan MA. Hal itu dapat didasarkan pada ketentuan Pasal 79 UU No. 14 Tahun 1985 jo UU No. 3 Tahun 2009 yang memberi kewenangan kepada MA untuk mengatur lebih lanjut hal-hal yang diperlukan bagi kelancaran penyelenggaraan peradilan atau untuk mengisi kekurangan dan kekosongan hukum akibat putusan MK.

Mengingat banyaknya putusan MK yang sudah membatalkan keberlakuan norma dalam berbagai undang-undang terkait perkara pidana, maka seharusnya DPR dan Pemerintah segera merevisi KUHP dan KUHAP agar tidak menimbulkan kekosongan hukum, sehingga dapat memberikan kepastian hukum dan keadilan bagi masyarakat. Kehadiran PERMA haruslah dipandang sementara waktu keberlakuannya sampai ditetapkannya norma baru dalam suatu UU yang telah diuji oleh MK.

\section{Daftar Pustaka}

\section{Buku}

Asshiddiqie, Jimly, Konstitusi \& Konstitusionalisme Indonesia, Diterbitkan atas kerjasama Mahkamah Konstitusi dengan Pusat Studi HTN FH Universitas Indonesia, Jakarta, 2004.

Fauzan, M. Peranan PERMA \& SEMA Sebagai Pengisi Kekosongan Hukum Indonesia Menuju Terwujudnya Peradilan yang Agung, Kencana Prenadamedia Group, Jakarta, 2013.

Huda, Ni'matul, Perkembangan Hukum Tata Negara Perdebatan \& Gagasan Penyempurnaan, FH UII Press, Yogyakarta, 2014

Kekuatan Eksekutorial Putusan Mahkamah Konstitusi, FH UII Press, Yogyakarta, 2018.

Laksana, Fajar, dkk., "Implikasi dan Implementasi Putusan Mahkamah Konstitusi No. 5/PUU-X/2012 tentang SBI atau RSBI", Jurnal Konstitusi, Vol. 10, No. 4, Desember 2013. 
Lumbuun, Ronald S., PERMA RI Wujud Kerancuan Antara Praktik Pembagian dan Pemisahan Kekuasaan, Rajawali Pers, Jakarta, 2011.

Martitah, Mahkamah Konstitusi Dari Negative Legislature ke Positive Legislature, Konpress, Jakarta, 2013

Siahaan, Maruarar, Hukum Acara Mahkamah Konstitusi RI, Konpress, Jakarta, 2005. UUD 1945 sebagai Konstitusi yang Hidup, Sekretariat Jenderal dan Kepaniteraan Mahkamah Konstitusi, Jakarta, 2008.

Tim Penyusun Buku Hakim Konstitusi Prof. H.A.S. Natabaya, SH, LLM, Menata Ulang Sistem Peraturan Perundang-Undangan Indonesia, Jejak Langkah dan Pemikiran Hukum Prof. H.A.S. Natabaya, SH, LLM, (Hakim Konstitusi Periode 2003-2008), Sekretariat Jenderal dan Kepaniteraan Mahkamah Konstitusi, Jakarta, 2008.

Tim Penyusun Buku, Putusan Landmark Mahkamah Konstitusi 2014-2016, Kepaniteraan dan Sekretariat Jenderal Mahkamah Konstitusi, Jakarta, 2017.

Undang-Undang Dasar Negara Republik Indonesia Tahun 1945

Undang-Undang Nomor 14 Tahun 1985 sebagaimana telah beberapa kali diubah, terakhir dengan Undang-Undang Nomor 3 Tahun 2009 tentang Mahkamah Agung ((Lembaran Negara Republik Indonesia Tahun 1985 Nomor 73)

Undang-Undang Nomor 24 Tahun 2003 tentang Mahkamah Konstitusi sebagaimana telah diubah dengan Undang-Undang Nomor 8 Tahun 2011 tentang Perubahan atas UU 24 Tahun 2003 tentang Mahkamah Konstitusi (Lembaran Negara Republik Indonesia Tahun 2003 Nomor 98)

Undang-Undang Nomor 12 Tahun 2011 tentang Pembentukan Peraturan Perundang-undangan. (Lembaran Negara Republik Indonesia Tahun 2011 Nomor 82)

Surat Edaran Mahkamah Agung Nomor 7 Tahun 2014 tentang Pengajuan Permohonan Peninjauan Kembali dalam Perkara Pidana.

Peraturan Mahkamah Agung (PERMA) Nomor 4 Tahun 2016 tentang Larangan Peninjauan Kembali Putusan Praperadilan.

Putusan Mahkamah Agung Nomor 103K/Pid/2007.

Putusan Mahkamah Agung Nomor 153PK/Pid/2010.

Putusan Mahkamah Agung Nomor 1110K/Pid.Sus/2012. 